\title{
Populações kaingang, processos de territorialização e capitalismo colonial/ moderno no Alto Uruguai (1941-1977)
}

\section{Kaingang people, territorialization process and colonial/modern capitalism in Alto Uruguay (1941-1977)}

\section{Pablo Quintero*}

* Universidade Federal do Rio Grande do Sul - Porto Alegre, RS, Brasil pablo.quintero@ufrgs.br https://orcid.org/0000-0003-4111-9895

Clémentine Maréchal**

**Universidade Federal do Rio Grande do Sul - Porto Alegre, RS, Brasil Doutoranda em Antropologia Social clementine.marechal08@gmail.com https://orcid.org/0000-0002-5676-3985 


\title{
Resumo
}

O artigo procura analisar as modalidades fundamentais da atuação dos órgãos estatais (Serviço de Proteção aos Índios, governo do estado do Rio Grande do Sul e Fundação Nacional do Índio) no Rio Grande do Sul entre a população kaingang do Alto Uruguai, mais especificamente da região de Votouro, entre 1941 e 1977. O trabalho utiliza diversas fontes secundárias e a memória histórica reunida junto aos Kaingang da região em diversos trabalhos etnográficos, para reconstruir e analisar os processos históricos mais importantes acontecidos nas relações entre Kaingang, os órgãos governamentais e as frentes de expansão agrícola do capitalismo periférico. A análise está centrada nas dinâmicas e processos agenciados por essas instituições para subordinar e explorar a população kaingang com o propósito de promover a acumulação do capital. Dessa forma, analisam-se as particularidades das relações de dominação, exploração e conflito desenvolvidas nesse contexto do capitalismo colonial/moderno. Abordar-se-á o sistema de panelão como expressão específica dessa modalidade de capitalismo na região, detalhando a articulação entre capitalismo colonial/moderno e subsunção formal do trabalho entre os Kaingang.

Palavras-chave: Kaingang; processos de territorialização; capitalismo colonial/ moderno; Rio Grande do Sul.

\begin{abstract}
The paper intends to analyze the main modalities of the Indian Protection Service's (SPI) activities in Rio Grande do Sul (Brazil) among the Kaingang population from Alto Uruguai, more specifically in Votouro region, between 1941 and 1977. This work uses several secondary sources and historical memory gathered along with Kaingang people in various ethnographic works, in order to reconstruct and analyze the most important historical processes occurred in the relationships among Kaingang people, the SPI and agricultural expansion front of peripheral capitalism. The analysis focuses on dynamics and processes managed by SPI in order to subordinate and exploit Kaingang population with purposes connected to capital accumulation. In this way, the paper examines particularities of domination and exploitation relationships and conflict developed in the context of colonial/modern capitalism. We approach the panelão system as a specific expression of this modality of capitalism in the region and we detail the articulation between colonial/modern capitalism and formal subsumption of work between Kaingang people.
\end{abstract}

Keywords: Kaingang; territorialization process; colonial/modern capitalism; Rio Grande do Sul. 


\section{Introdução}

Desde a perspectiva da antropologia histórica, o presente artigo procura analisar os resultados fundamentais da atuação dos órgãos estatais Serviço de Proteção aos Índios (SPI), governo do estado e Fundação Nacional do Índio (Funai) no estado do Rio Grande do Sul junto aos grupos de população kaingang do Alto Uruguai, mais especificamente na região de Votouro, entre os anos de 1941 e 1977. ${ }^{1}$ O trabalho utiliza diversas fontes secundárias e a memória histórica reunida junto aos Kaingang da região - presente em diversos trabalhos etnográficos - para reconstruir e analisar alguns dos processos históricos mais importantes tramados nas relações entre os Kaingang, o SPI (que posteriormente veio a se tornar a Funai) e as frentes de expansão agrícola, produzindo uma específica formação social do capitalismo periférico.

A análise está centrada nas diversas dinâmicas e processos agenciados pelos órgãos estatais para subordinar e explorar a população kaingang visando a acumulação do capital. Dessa forma, analisam-se as particularidades das relações de dominação, exploração e conflito forjadas nesse contexto específico do capitalismo colonial/moderno (Quintero, 2013) através da concatenação das trajetórias centrais dos processos de expropriação dos territórios indígenas, sedentarização e relocalização, controle repressivo da população, reconfiguração da organização social e dependência do setor capitalista para a reprodução da vida.

Nesse sentido, abordar-se-á o sistema de panelão como expressão particular dessa modalidade de capitalismo entre os Kaingang do Alto Uruguai,

1 O Toldo Votouro foi administrado pelo governo do estado do Rio Grande do Sul até meados dos anos 1960. Porém, a atuação indigenista estadual, embora tenha sido independente do órgão federal, tem reproduzido modos de atuação muito parecidos com o SPI, inclusive o sistema de panelão que abordaremos a seguir. Na memória dos Kaingang, aquele tempo, que se estende para além da extinção do SPI em 1967, é conhecido como "tempo do SPI", mesmo que tal órgão tenha sido implementado no toldo tardiamente, pois as modalidades de atuação dos funcionários inspiravam-se da política do SPI, chegando, inclusive, a praticar um verdadeiro "terror", como no Toldo Ventarra (Simonian, 1994). Tais práticas se prolongaram e assumiram novas formas após a implementação do órgão indigenista atual, a Funai. O recorte temporal que escolhemos aqui (1941-1977) baseia-se, dessa maneira, na articulação entre a memória dos Kaingang entrevistados, o início da atuação oficial do SPI e o começo do que o historiador kaingang Danilo Braga (2015) chamou de "reação indígena", isto é, um movimento político que dará nascimento às primeiras retomadas kaingang no fim dos anos 1970 e início dos anos 1980. 
detalhando-se a articulação entre capitalismo colonial/moderno e subsunção formal do trabalho entre a população indígena da região.

\section{O Serviço de Proteção aos Índios e a colonialidade do poder}

O Serviço de Proteção aos Índios e Localização dos Trabalhadores Nacionais (SPILTN) nasce em 1910 sob o incentivo do Marechal Cândido Rondon como parte do exercício de (re)colonização das populações indígenas organizados por diversos organismos do Estado-nação brasileiro. Em 1918 o nome de origem foi abreviado para Serviço de Proteção aos Índios (SPI). Essa nova denominação ajudou a mascarar as caraterísticas e objetivos fundamentais do organismo, que até 1930 dependeria diretamente do Ministério de Comércio e da Agricultura. Sob o argumento de difundir entre os indígenas uma ideologia indigenista (Ramos, 1998) fortemente influenciada pelo movimento positivista, os verdadeiros objetivos do SPI estavam baseados na expansão e exploração das terras agrícolas ${ }^{2}$ e, posteriormente, na utilização de mão de obra indígena nessa expansão.

A partir da metade do século XIX, a gestão governamental sobre os indígenas passa a ser mais sistemática. $O$ decreto $\mathrm{n}^{\circ} 426$ de 24 de julho de 1845 estabelece o "Regulamento acerca das Missões de Catequese e Civilização dos Índios" (Brasil, 1845) - mais conhecido como "Regimento das Missões". Este consiste em uma tentativa de controle social das populações indígenas colocada em prática a partir de uma articulação entre o aparato militar do império e as missões religiosas capuchinhas. Do Regimento das Missões surgirá a política oficial dos aldeamentos, que terá como objetivo concentrar os indígenas em espaços reduzidos para a expansão agrícola. Tais processos de territorialização (Pacheco de Oliveira, 2004) desenvolveram-se através de uma política de "pacificação" (Pacheco de Oliveira, 2016) que consistia em atrair e encerrar os indígenas "bravos" em territórios controlados pelos agentes indigenistas, bem

2 Paralelamente, em 1850, a lei nº 601, mais conhecida como Lei de Terras (Brasil, 1850), é implementada em todo o país e serviria como um dos mais eficazes instrumentos de espoliação territorial dos indígenas. Essa lei determinava que as terras só poderiam ser adquiridas através de compra e deliberava quais seriam as terras devolutas do império. Inserida num contexto de liberalismo econômico, o objetivo dessa lei era proteger os interesses dos fazendeiros. 
como em castigar com tortura qualquer tentativa de rebeldia dos indígenas que não aceitavam serem "pacificados"3 (Lima, 1995).

Certamente, a "pacificação" orientava-se pela busca da "integração" dos indígenas à sociedade nacional brasileira, afinal, o nascimento do SPI remete diretamente à construção e ao fortalecimento do Estado nacional brasileiro. Em 1928, o SPI classificou os indígenas em quatro categorias que orientariam suas políticas civilizatórias: a) índios nômades; b) índios aldeados ou arrendados; c) índios pertencentes a povoações indígenas; d) índios em centros agrícolas ou que vivem promiscuamente com os civilizados (Lima, 1995). Essas categorias devem ser entendidas como parte de um imaginário evolucionista segundo o qual os indígenas eram apreendidos através de uma escala de desenvolvimento civilizatório cujo nível subiria conforme o grau de contato e proximidade com o órgão indigenista. As diferenças étnicas eram formuladas através de categorias inventadas que se referiam ao grau de "civilização" dos indígenas, divididos entre "índios mansos" e "indios bravos". Os indígenas considerados como "selvagens" eram os melhores alvos dessas políticas, já que não tinham contraído "defeitos" pelo contato com outras frentes colonizadoras. Para ter ou manter um controle total sobre os indígenas o SPI procurou garantir o monopólio da sua assistência (Lima, 1995).

As identidades étnicas passaram a ser diluídas na identidade nacional através de uma série de mecanismos que os órgãos e instituições pertencentes ao Estado se empenharam em usar com o intuito de congregar as populações originárias ao redor de uma série de novos imaginários de corte nacionalista. Embora visassem se tornar "comuns" para o "povo brasileiro", tais imaginários eram, na realidade, a expressão de normas e valores "ocidentais" que passaram a ser ressignificados no contexto "nacional".

3 Os debates indigenistas da Primeira República davam-se no âmbito do Instituto Histórico e Geográfico Brasileiro (IHGB) com base em duas opções: o extermínio dos índios ou a sua assimilação à sociedade nacional. O Serviço de Proteção aos Índios nasce, nesse sentido, como "alternativa" à afirmação feita por Von Ihering, de que, considerando os indígenas como um empecilho à colonização do sertão, deveriam ser exterminados. Diante de tal postura, intelectuais influenciados pelo positivismo e iluminismo defendiam uma atuação do Estado no processo civilizatório dos indígenas. É a partir dessa polêmica que surge, em 1910, o SPI, que, como ressaltaram já inúmeros autores assim como o próprio relatório Figueiredo, instaurou uma sistematização da violência colonial em todos os territórios indígenas onde seus funcionários atuaram. 
Nesse panorama, o SPI atuou como uma instituição encarregada de desenvolver duas tarefas integradas e complementares: implementar um projeto civilizatório (Bonfil Batalla, 1987) que permitiria pacificar e "domesticar" os indígenas a fim de usá-los - eis a segunda tarefa - como mão de obra superexplorada no projeto desenvolvimentista para o aproveitamento da (re)expansão capitalista. Ambos os processos podem ser compreendidos como integrantes estruturais de uma matriz de poder moderno/colonial articulada com as dinâmicas do capitalismo periférico que se desenvolvem em diversas modalidades de dominação subjetiva associadas, ao mesmo tempo, com formas de exploração do trabalho. Esta vinculação estrutural entre dinâmicas de (re)identificação e classificação social baseadas nas ideias de raça/gênero/classe e processos de controle e exploração trabalho foi denominada por Aníbal Quijano $(1992,2000)$ como colonialidade do poder e apontada pelo sociólogo peruano como a caraterística fundamental das formações sociais na América Latina, ou seja, a base estruturante de suas sociedades. Nesse sentido, o termo "colonialidade", longe de designar uma "herança" do colonialismo europeu reproduzida na América pós-colonial, refere-se a um modelo específico de dominação, exploração e conflito originado com a expansão global do colonialismo, reconfigurado e reatualizado ao longo do tempo histórico da modernidade que, como um sistema ordenador e acumulativo, estrutura as relações sociais na América Latina através da hegemonia do Estado (Quintero, 2014). ${ }^{4}$

4 É preciso insistir nas diferenças entre os conceitos de colonialismo, colonialismo interno e colonialidade do poder. O primeiro remete a uma forma de subordinação político-econômica na qual a soberania de uma população está submetida ao controle de outra sociedade que se pensa "externa" à população dominada. Em contraposição, a ideia de "colonialismo interno", proposta na América Latina principalmente por Pablo González Casanova (1965) e Rodolfo Stavenhagen (1969), tenta resgatar a dimensão intranacional do fenômeno colonial especificando espacialmente a categoria para ser pensada "dentro" das nações latino-americanas como sociedades duais ou plurais formadas por relações entre classes dominantes e classes dominadas (Quintero, 2013). Apesar das interessantes contribuições deste último, o conceito de colonialidade do poder de Quijano permite uma exploração mais profunda, histórica e estruturalmente, da questão colonial, pois rompe com as noções de externalidade e internalidade das relações coloniais (Quintero, 2019), adotando uma perspectiva mais flexível e, ao mesmo tempo, mais complexa. 


\section{A população kaingang, a Diretoria de Terras e Colonização e o Serviço de Proteção aos Índios no Rio Grande do Sul}

A população kaingang conta com mais de 45.000 pessoas que habitam os estados de Rio Grande do Sul, Santa Catarina, Paraná e o sul de São Paulo, formando, assim, o terceiro maior grupo indígena do país. Pertencem ao tronco linguístico jê e um dos pilares da sua organização social encontra-se na complementariedade ancorada num sistema cosmológico dualista. Foram chamados de Gualacho e Chiqui pelos padres jesuítas no século XVII, de Guaianá por parte da literatura histórica paulista do final do século XIX e início do século XX, e de Coroado pelos agentes do Estado e religiosos nos séculos XIX e XX, assim como pela sociedade envolvente (Mota, 2004). Segundo Becker (1976), foi durante o século XX que se convencionou chamá-los de Kaingang, um etnônimo que, segundo a pesquisadora, não deixa de ser uma generalização para satisfazer aos antropólogos.

Segundo Laroque (2000), o mais antigo registro que se refere a essas populações aparece no "Tratado descritivo do Brazil em 1587", escrito por Gabriel Souza Soares, que menciona os "Goaianaze" ocupando a costa litorânea desde Angra dos Reis até Cananéia. Esses indígenas tinham uma língua diferente da de seus vizinhos identificados como Tamoio e Carijó e protegiam seus territórios mantendo-se num estado de guerra contra os invasores. Ainda segundo o historiador, os Goaianaze, ancestrais dos atuais Kaingang, não praticavam a antropofagia, mas tinham o costume de escravizar seus prisioneiros de guerra. Eram pescadores, caçadores e coletores, e habitavam "covas pelo campo de baixo do chão, onde tem fogo de noite e de dia e fazem camas de rama e pelles de alimárias que mataram" (Souza, 1878 apud Laroque, 2000, p. 45).

No século XVII, os Guaianá são mencionados pelo padre jesuíta Simão de Vasconcelos na crônica da Companhia de Jesus. Além de relatar as frequentes guerras dos Guaianá com os Carijó, o padre afirma que, em decorrência da superioridade bélica portuguesa, muitas tribos de "índios bárbaros" tinham começado a migrar pelo extremo sul em direção ao rio da Prata (Laroque, 2000). Nesse sentido, Francisco Schaden (1963) menciona uma redução jesuítica em 1630 no território do Guándana, no alto curso do rio Uruguai, com cerca de 3000 índios. Segundo Laroque (2000), essa redução, chamada de Conceição, seria o resultado de uma iniciativa dos padres Ruiz de Montoya 
e Francisco Dias Taño, que fizeram contato com os indígenas mostrando-lhes a potência das armas de fogo e oferecendo-lhes farinha de mandioca e de milho. No território paranaense, Tommasino (1995) menciona que foram fundadas 13 reduções às margens dos rios Paranapanema, Piquiri, Pirapó, Tibagi e Ivaí.

Em 1628, Raposo Tavares, bandeirante paulista e armado da Casa Real, dirigiu-se ao território do Guairá (atual província do Paraná) com o objetivo de levar para São Paulo os indígenas catequizados e "mansos" e de torná-los escravos. Regressará a São Paulo em maio de 1629 com mais de 20.000 índios escravos (Wachovics, 1988 apud Tommasino, 1995, p. 61).

Houve entre 1722 e 1734 várias tentativas de reduções na região do rio Uruguai. Entre 1728 e 1730 constrói-se a primeira etapa do "Caminho da Mata", que permitiria o transporte de gado até Sorocaba. Esse caminho partia do Morro dos Conventos, no litoral de Santa Catarina, e atingia os campos de São Joaquim, Lages e Curitibanos. Passando pelo interior do planalto meridional, o caminho era mais curto que o trajeto pela costa. Em 1738, o "Caminho da Tropa" é criado, ligando os campos de Lages ao Rio Grande do Sul via região da Serra (Laroque, 2000).

Mesmo com os primeiros processos coloniais, as florestas de araucárias habitadas pelos Kaingang permaneciam sendo, como ressalta Laroque (2000), "terras de índio", notadamente devido à capacidade guerreira dos Kaingang em defender seus territórios. A partir da metade do século XIX, com a política oficial dos aldeamentos, toda uma série de relações que os Kaingang desenvolviam com seu território e entre si passou a ser modificada consideravelmente. Sedentarizados, os Kaingang foram forçados a trabalhar em lavouras e a frequentar as primeiras escolas onde o uso do português tornou-se obrigatório e o uso da sua língua nativa, proibido. Entretanto, um dos maiores objetivos dos aldeamentos no sul do país foi a "liberação" das terras para a chegada de colonos europeus, que desde a segunda década do século XIX foram incentivados pelo império a "povoar" e desenvolver o Brasil.

A política indigenista no Rio Grande do Sul no final do século XIX e início do século XX era desenvolvida pela Diretoria de Terras e Colonização (DTC), submetida à Secretaria das Obras Públicas. Com a chegada dos colonos italianos entre o final do século XIX e o começo do século XX, o governo do estado do Rio Grande do Sul procurou demarcar as terras, deixando as menos férteis para a demarcação dos toldos indígenas. Foram demarcados, entre 1911 e 1918, 
12 toldos indígenas kaingang no Rio Grande do Sul: Inhacorá, Guarita e Nonoai (pertencendo ao município de Palmeira das Missões); Serrinha, Fachinal e Caseiros (no município de Lagoa Vermelha); Lagoão (município de Soledade), Carreteiro, Ventarra, Erechim, Votouro e Ligeiro (município de Passo Fundo).

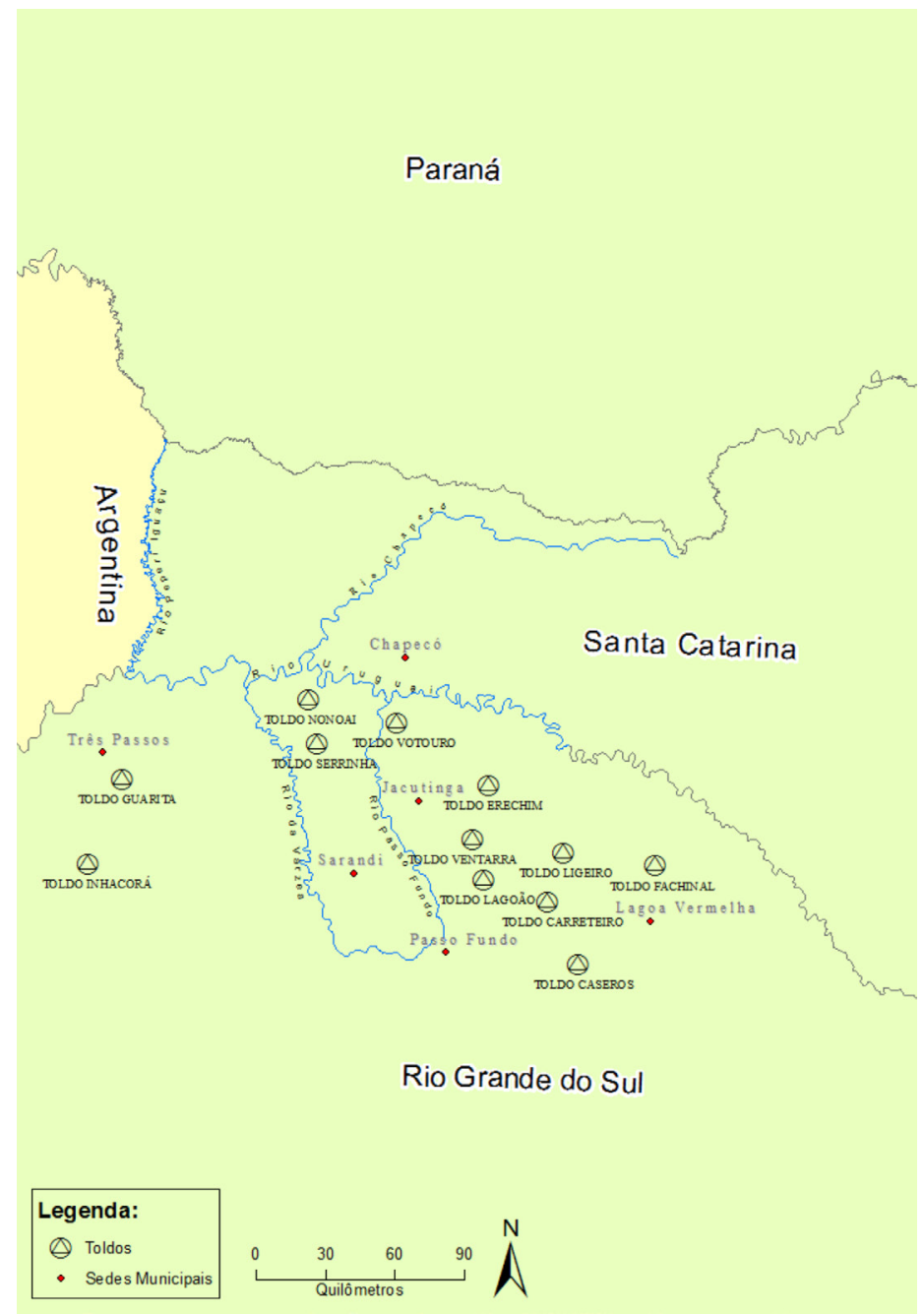

Figura 1. Mapa com a localização dos toldos indígenas nas regiões norte e noroeste do Rio Grande do Sul, demarcados pela DTC entre 1911 e 1918 (cf. Bringmann, 2015, p. 53). 
A Diretoria de Terras e Colonização era um órgão central que se dividia em várias seções regionais, as Comissões de Terras e Colonização (CTC). Cada comissão era representada por um chefe, nomeado por indicação da DTC, que tinha certa autonomia na sua atuação. A DTC, preocupada com a questão indígena, buscou nomear para cada CTC um "mestre carpinteiro" que teria como funções "ajudar no desenvolvimento do toldo" e ensinar o básico para as crianças (ler, escrever, etc.).

Embora o governo do estado do Rio Grande do Sul, através da DTC e das suas comissões regionais, tenha implementado os pilares de um projeto civilizatório para os indígenas - baseado, sobretudo, na "limpeza" das terras, para que se tornassem aptas à agricultura e ao confinamento das populações indígenas -, a iniciativa estadual não teve as mesmas características da atuação do órgão indigenista federal até meados do século XX. O projeto do SPI, além de buscar transformar as terras habitadas pelos indígenas em mercadorias, implementou um projeto de nacionalização do território e dos seus habitantes. A dominação e o controle exercidos sobre os indígenas a partir dos anos 1930, quando começa a "era Vargas", tornam-se ainda mais virulentos. Durante a gestão do SPI, entre 1910 e 1967, foram instalados 59 postos indígenas (PI) nos estados de Santa Catarina, Paraná e Rio Grande do Sul que responderam à Inspetoria Regional 7 (IR7) (Freire, 2011). Entretanto, vários toldos que tinham sido demarcados entre 1911 e 1918 pela DTC ficaram a cargo do governo do estado até a metade da década de 1960, por intermédio da administração da Secretária de Agricultura e das Inspetorias de Terras das diferentes regiões do Rio Grande do Sul, como nos casos do Toldo Votouro e do Toldo Ventarra - este último sendo extinto em 1962 e recuperado posteriormente pelos Kaingang na década de 1990.

Para os órgãos indigenistas, o "destino final" dos indígenas era o mercado de trabalho rural. Assim, o órgão se empenhou em controlar as entradas e saídas das reservas a fim de evitar que os Kaingang migrassem para as cidades. Os seus territórios passaram a ser controlados por uma administração nacional e suas terras, transformadas em mercadorias potenciais.

Nesse sentido, o Estado brasileiro, através da sua representação estadual e federal, atuou nos territórios indígenas como um aparelho de controle social a serviço do capital. Dessa maneira, o projeto civilizatório implementado pelos órgãos indigenistas brasileiros não pode ser entendido sem se levar em conta 
a inserção dependente do Brasil no capitalismo mundial (Cardoso de Oliveira, 1964; Pacheco de Oliveira, 1998; Velho, 1981). Assim, o SPI - tal como alguns representantes do governo estadual do Rio Grande do Sul ${ }^{5}$ - buscou transformar o cimento da organização social, política, econômica e intersubjetiva dos Kaingang com o objetivo de facilitar sua "assimilação" ao sistema produtivo capitalista. O SPI conformou-se, então, como uma estrutura que centralizava diferentes modalidades de dominação e exploração social que visavam o controle não somente do território, mas, também, das populações indígenas. O controle social foi implementado nos postos indígenas a partir da figura do chefe do posto, que fortaleceu sua autoridade através da formação de uma polícia indígena encarregada de aplicar os castigos sobre outros indígenas. Escolas, postos de saúde e oficinas foram criados e configuraram-se como potentes mecanismos de controle social e de transformação sociocultural das populações indígenas. Essa estrutura também será reforçada a partir de uma busca pela individualização das pessoas, com a decorrente obrigação de possuírem uma carteira de identidade individual, o que permitiu à administração um maior monitoramento das pessoas. Dessa forma, a centralização do poder tutelar sob a administração do órgão indigenista contribuiria de maneira fundamental para a pacificação, a "civilização" e a transformação dos povos indígenas em mão de obra. A atuação do SPI entre os Kaingang deve ser entendida, nos termos de Lima (1995), como uma rotinização da guerra de conquista.

No começo da década de 1940, no Rio Grande do Sul, são criados quatro Postos Indígenas de Assistência, Nacionalização e Educação (PIN): o PIN Guarita, o PIN Cacique Doble, o PIN Nonoai e o PIN Ligeiro (que desde 1911 encontrava-se sob gestão federal). Esses PIN foram submetidos à autoridade da IR7 e a cada um deles foram enviados administradores (chefes de posto) que, por vezes, eram de outras regiões do país. Em relação ao restante dos toldos indígenas, a partir de 1956 eles passaram a ser administrados pela Inspetoria Florestal ( $4^{\mathrm{a}}$ Inspetoria de Terras). Porém, devemos considerar a influência das

5 No Rio Grande do Sul há registros de diversas formas da atuação do governo do estado nos toldos indígenas. Na gestão do SPI, dependendo do chefe do posto, a política administrativa e de controle social dos indígenas podia mudar de forma significativa. No caso do Toldo Votouro, é sobretudo a partir dos anos 1960 que uma política repressiva se instaura em estreita correlação com a intensificação da exploração do seu trabalho tanto na extração de madeira quanto nas lavouras coletivas. 
políticas do SPI sobre os toldos que permaneceram sob gestão estadual. Era comum, por exemplo, que os funcionários do órgão federal visitassem os toldos vizinhos no intuito de agrupar as comunidades desses toldos à gestão do SPI. O kujà (liderança espiritual kaingang) Jorge Kagnãg Garcia, que mora na TI Nonoai, relatou em uma entrevista em janeiro de 2020 que durante a época do SPI "as lideranças vinham em Nonoai para fazer uma ideia de como que podia trabalhar com os índios”. É dessa maneira que o sistema de panelão - assim como outras ferramentas de controle social e de repressão - foi implementado também nos toldos indígenas (Simonian, 1994).

O órgão do Estado agenciou a força de trabalho dos Kaingang com a finalidade de se inserir na economia regional e nacional como uma entidade produtiva estatal. Essa nova gestão trouxe uma política diferente em relação às terras indígenas, que se tornaram alvo de iniciativas governamentais de colonização.

\section{Despossessão dos territórios kaingang e subordinação ao Estado e ao capital no Alto Uruguai}

A atuação do SPI entre os Kaingang do Rio Grande do Sul articulou-se com as dinâmicas regionais de acumulação de capital. Antes mesmo da implementação do SPI no Rio Grande do Sul em 1941, os fiscais dos índios - funcionários da DTC - forçaram a inserção dos indígenas em um novo regime de exploração do trabalho que aproveitava as características das economias domésticas kaingang. O primeiro passo para essa inserção forçada foi a sedentarização da população kaingang, que começou a ser implementada de forma mais sistemática com a política oficial dos aldeamentos a partir de 1845. Hoje, parte das terras indígenas (TI) kaingang demarcadas e homologadas pelo Estado brasileiro são oriundas dos primeiros aldeamentos - Nonoai, por exemplo, foi demarcada pela primeira vez em 1846. ${ }^{6}$ Porém, após as primeiras demarcações, os "toldos" onde foram confinados os Kaingang passaram por uma série de contínuas

6 Em 1856, seus limites foram finalmente definidos e a área totalizava "10 léguas em quadrado" (Becker, 1976, p. 61) tendo como limites ao norte o rio Uruguai; ao sul, o lajeado Papudo; a leste o rio Passo Fundo; a oeste, o rio da Várzea. A demarcação desse território por parte do governo provincial tinha por objetivo reunir os diversos grupos Kaingang que habitavam a região apenas em um aldeamento a fim de liberar as terras para a chegada de colonos europeus. 
reduções. Na época do SPI, vários grupos e unidades domésticas kaingang foram "transferidas" forçadamente a outros PI ou toldos. Essas realocações formavam parte do processo geral de espoliação dos territórios indígenas que culminou com a obrigação feita aos Kaingang de trabalhar nas lavouras contíguas aos PI.

Nonoai teve, por exemplo, grande parte da sua terra original transformada em uma Reserva Florestal Estadual e em lotes rurais para assentamentos de agricultores. Em 1942, o governo do estado validou a expropriação de uma gleba de 622 hectares da TI Serrinha (RS) (Simonian, 2009). O período entre 1949 e 1963 é conhecido como a época das expropriações. O governador Leonel Brizola, afiliado ao Partido Trabalhista do Brasil (PTB), tinha a intenção de empreender, no Rio Grande do Sul, uma reforma agrária com o objetivo de devolver a terra aos camponeses, já que estas eram ocupadas por uma minoria de fazendeiros. Ele criou o Instituto Gaúcho de Reforma Agrária (Igra), institucionalizando, assim, o empreendimento. $\mathrm{O}$ instituto prestava assistência aos agricultores, além de oferecer financiamento para máquinas, sementes e animais. O governador articulou e acompanhou o Movimento dos Agricultores Sem Terra (Master). Muitos camponeses e pequenos produtores vieram a se beneficiar dessas políticas de redistribuição da terra. Brizola decidiu, porém, intensificar a reforma agrária nas terras indígenas, argumentando que tinha "muita terra para pouco índio" (Simonian, 2009). Entretanto, foram as elites locais que se aproveitaram de tal política para favorecer seus interesses econômicos e, assim, expulsaram os indígenas dos seus territórios. Em Ventarra, por exemplo, o toldo kaingang foi totalmente extinto e, segundo o cientista social Rodrigo Venzon, ${ }^{7}$ o território não foi entregue aos agricultores sem terra. Na verdade, grande parte dele foi cedido às iniciativas privada e pública para a extração de madeira. As famílias kaingang que moravam nesse toldo foram transferidas para outros toldos e postos indígenas entre 1962 e 1964. Muitas delas foram realocadas no Toldo Votouro, que também tinha sido reduzido consideravelmente ( 1515 hectares a menos, sendo 883 destinados para agricultores não indígenas e outros 632 para uma reserva florestal). Outros grupos kaingang foram enviados aos PI de Nonoai, Ligeiro e Charrua. Esses deslocamentos

7 Comunicação pessoal, em Porto Alegre, novembro de 2019. 
provocaram uma desestruturação na organização social dos Kaingang oriundos de Ventarra, que foram obrigados, por um lado, a abandonar seu território, suas casas e plantações, e, por outro, a responder a uma nova autoridade indígena subordinada a uma autoridade indigenista, que manifestava seu poder criando tensões internas entre os Kaingang oriundos de Ventarra e os que já moravam no Toldo Votouro.

Efetivamente, tais deslocamentos forçados - combinados com uma importante redução do Toldo Votouro - provocaram uma série de tensões entre os Kaingang. Rodrigo Venzon relata que quando os Kaingang de Ventarra chegaram no Toldo Votouro, os Kaingang que ali moravam foram expulsos das suas casas:

Quando os Kaingang de Ventarra foram levados para Votouro, os Kaingang de Votouro foram expulsos das suas casas e tiveram que ficar morando no mato. Além disso, o loteamento da seção Tupi já tinha acontecido. Então a área já tinha sido reduzida. Eles foram todos despejados e foram pro mato e daí alguns Kaingang de Ventarra ganharam parte das casas. Dizem que passaram dois anos até eles começarem a conversar, pela questão da injustiça. Os brancos colocaram um grupo contra outro.

Assim, grupos familiares Kaingang - que não necessariamente se conheciam ou cujos antepassados já tinham tido desavenças - foram forçados a habitarem um mesmo território em um contexto de redução drástica do espaço. Expulsar os Kaingang de Votouro da Barra Seca e do Tico-Tico ${ }^{8}$ para que ali se instalassem os grupos oriundos de Ventarra foi uma estratégia dos funcionários do governo para consolidar seu poder no território indígena. Por um lado, colocavam a responsabilidade da expulsão dos Kaingang de Votouro nas costas das famílias que recém chegavam de Ventarra, e, por outro, com a entrega de casas e terras para os Kaingang oriundos de Ventarra, asseguravam-se da colaboração das antigas lideranças de Ventarra para a administração do Toldo Votouro. ${ }^{9}$

8 Esses eram os dois locais, no interior do Toldo Votouro, onde foram realocados os Kaingang de Ventarra.

9 Não é por acaso que vários grandes caciques da TI Votouro são oriundos do Toldo Ventarra, como Vidal Paulo, que assumiu o cacicado da TI ainda na década de 1960 (Rosa, 2005, p. 290). $\rightarrow$ 
Reproduzindo as armadilhas do poder tutelar, com as máscaras do cuidado e da assistência, os funcionários estatais escondiam seus verdadeiros interesses: a ancoragem do seu poder político e econômico no território. As rivalidades entre estas famílias se intensificariam e os funcionários as utilizaram durante anos como um instrumento muito efetivo de dominação (Pacheco de Oliveira, 2015).

Alguns desses Kaingang oriundos de Ventarra que foram deslocados no início dos anos 1960 moram hoje na TI Kandóia, cujos habitantes, como Valério de Oliveira, estão aguardando há 18 anos a demarcação:

Na época eles mandaram para nós um carro, né, um caminhão. Como éramos bastante, um caminhão bem velho, antigo, ele encostou e, de repente, passam os índios, a polícia. Mandaram até polícia dos índios lá para avisar o pessoal. Todo mundo chorava porque não queriam deixar do lugar deles, né, que éramos acostumados lá. Os velhos ficavam tristes, meu Deus do céu, é que não sabiam por onde que estavam indo. (Entrevista com Valério de Oliveira, junho de 2017, TI Kandóia).

Também Batista de Oliveira foi deslocado de Ventarra até o Toldo Votouro e nos conta:

Trouxeram nós acima de um caminhão, que nem boi. Era umas 45 famílias. Nós até de medo de polícia nós fomos. Nos trouxeram de lá no tal de Tico-Tico. Fica lá no fundo. Ficamos lá sofrendo, prometeram comida para nós e quando chegamos aqui, pam: acabou a promessa, daí. Na verdade, quando nós chegamos aqui não tinha nada, ficamos abandonados, deixaram nós no tempo que nem quem joga um gado na invernada, cada um depois se vira, faz uma casa de capim, de taquara. Eles falaram que iam mandar nós para uma terra melhor, que iam dar tudo, não sei o quê, com mais recursos, mas, na verdade, foi só conversa deles e daí ficamos por aqui, estamos aqui até agora. (Entrevista com Batista de Oliveira, agosto de 2017, TI Votouro).

$\rightarrow$ Nas décadas seguintes, Batista de Paula e Jacir de Paula, ambos oriundos de Ventarra, assumiriam o cacicado. Batista de Oliveira, que também veio de Ventarra, assumiria o cacicado de Votouro na década de 1990. 
Dessa maneira, foram negados aos indígenas seus modos próprios de produção e de reprodução social, que se fundamentam em uma relação intensa com a floresta, nãn, pois a produção e reprodução socioeconômica kaingang se baseava principalmente na caça, na pesca e na colheita. O convívio com a floresta, além de promover os meios de subsistências para os Kaingang, permite o fortalecimento de relações sociais com seres específicos relacionados a esse domínio e que devem ser entendidas como necessárias à sua reprodução social. Luís da Silva conta como antigamente seu pai caçava na floresta, hoje convertida em monocultura de exportação:

Caçava quati, caçava, como que se diz o veado, fãfã, inh, inh é tatu, né. Porco do mato diz que por aqui existia, aqui mesmo existia, como tinha mato. Hoje não tem mais, nem madeira não tem mais, nem fruta. Só existe fruta do que eles prantaram, eles têm arrancado tudo. (Entrevista com Luís da Silva, julho de 2017, TI Kandóia).

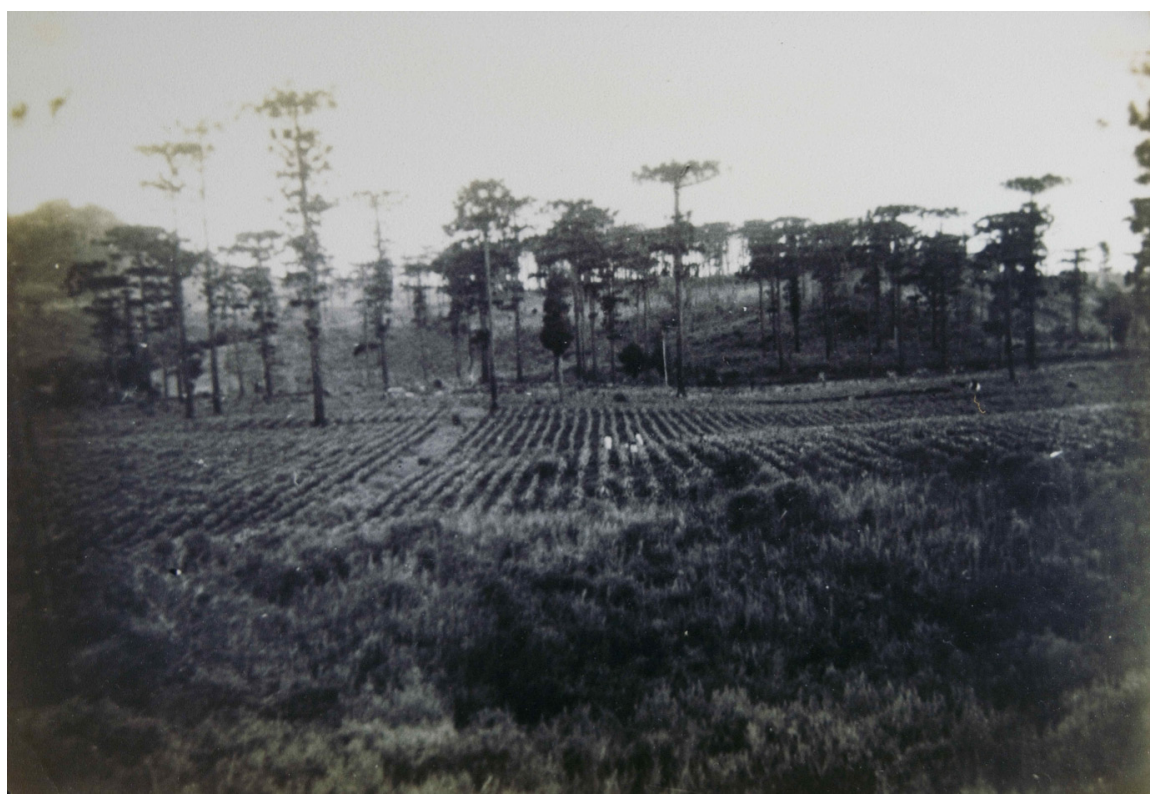

Figura 2. Floresta transformada em lavoura. PI Ligeiro (RS) - SPI/IR7, 1944.

Fonte: Acervo do Museu do Índio/Funai - Brasil. 
A ideia de despossessão não pode ser entendida simplesmente como uma expropriação de bens materiais. Despossuir é também desapoderar: ao restringir as possibilidades de reprodução dos processos subjetivos articulados com o mundo cosmológico autônomo (Godelier, 1982) através da expropriação da terra, os indígenas ficam despossuídos das suas relações com ela. Sendo obrigados a desmatar as florestas para o comércio de madeira, os Kaingang foram forçados a se desapossar de uma série de relações antigas que mantinham com $o$ universo da floresta. Essas relações, permeadas pelo kanhgág jykre (pensamento kaingang), são regidas por regras específicas que visam a manutenção do equilíbrio social entre os Kaingang e os seres da floresta. Os Kaingang consideram que cada ser possui um tón correspondente a um estado animado. Por isso, as árvores sentem dor e deveriam ser tratadas com cuidado, e o corte de cada uma delas teria de passar por um pedido de licença ritual prévia (Maréchal, 2017). Assim, buscar a transformação dos indígenas em agricultores implicou também a despossessão da terra no seu aspecto cosmológico - ou seja, as relações que os Kaingang desenvolviam com a floresta - uma vez que foram forçados a destruí-la sob as ordens dos agentes estatais e privados: os indígenas foram especificamente obrigados a trabalhar na produção agrícola, na criação de currais para pecuária e na extração dos recursos florestais - dois setores fortes da economia regional da época (Almeida, C., 2017).

O projeto do SPI que originalmente visava a autossuficiência do indígena (Lima, 1992) valia-se, na verdade, de velhas formas de aproveitamento do trabalho nativo pelo capitalismo colonial/moderno e se sustentava das "diferenças" étnico/raciais para desenvolver os mecanismos centrais da subordinação da mão de obra nativa (Alatas, 2010). Supostamente, o SPI deveria centralizar a produção a fim de logo redistribuí-la para as famílias kaingang. Em caso de excedente, era previsto utilizar a venda da superprodução para a construção de posto de saúde, escolas e oficinas ligadas à instituição do SPI, ou seja, investir o dinheiro para o fortalecimento do projeto nacional-civilizatório. Porém, muitos relatos dos Kaingang afirmam que: 1) eles tiveram de trabalhar "em troca de comida"; 2) os excedentes de produção eram comercializados e o dinheiro se perdia nos bolsos dos funcionários do órgão estatal.

Os processos de privatização do espaço e de geração de propriedade privada da terra constituem um pré-requisito fundamental nas dinâmicas da acumulação de capital, tanto na expropriação de recursos naturais quanto na 
exploração da força de trabalho - neste último caso, afastando e estranhando os produtores dos seus meios de subsistência (Marx, 2010). Os territórios que estavam sob o controle do SPI e do governo do estado eram terras de domínio público e funcionavam de acordo com o sistema de produção capitalista. Os órgãos buscaram se adequar à dinâmica econômica regional, tendo como objetivo principal a transformação dos indígenas em trabalhadores agrícolas e explorando sua mão de obra na extração de madeira. É evidente que sem a intervenção do Estado a despossessão territorial e a subordinação laboral não seriam possíveis. É somente com o uso das suas forças e com a sua gestão política centralizadora, sob a tutela do SPI, que se conseguiu implementar um sistema de exploração do trabalho entre os Kaingang, denominado pelos próprios indígenas como o sistema de panelão.

\section{O sistema de panelão como expressão do capitalismo colonial/moderno}

O panelão é o nome que os indígenas deram ao trabalho forçado em troca de comida implementado pelo SPI a partir da década de 1940 nos PI e nos toldos kaingang no estado do Rio Grande do Sul (Braga, 2015). Eles foram obrigados a trabalhar principalmente em lavouras coletivas, na abertura de estradas e na extração de madeira. Segundo Bringmann (2015), no PI Nonoai os Kaingang tinham que trabalhar alguns dias da semana para o posto. Caso contrário, podiam receber algum tipo de castigo. As lavouras coletivas provocaram muitos desequilíbrios no modo de viver dos Kaingang. Algumas roças familiares foram abandonadas em prol de uma dedicação exclusiva de trabalho para 0 posto.

A denominação de panelão foi dada pelos Kaingang porque a comida, cozinhada pelas mulheres kaingang, era servida em grandes panelas. Batista de Oliveira lembra:

Quando nós chegamos aqui [no Toldo Votouro] era o tal de panelão e daí tinha as cozinheiras e tudo o pessoal que trabalhava na lavoura, era duas ou três cozinheiras sempre no panelão e dali eles davam qualquer tipo de comida para nós trabalhar na lavoura do chefe, né. Nunca pagaram nós, nunca foi pago. Aí no 
panelão o que nós ganhava era só feijão, arroz, café, era só comida e ruim ainda, com pouca banha. Eles traziam o feijão lá de Charrua, farinha também. Não foi fácil nossa convivência, para se adaptar não foi fácil. Nunca deram roupa só comidinha e deu comida que hoje serve para meus cachorros. (Entrevista com Batista de Oliveira, agosto de 2017, TI Votouro).

Pedro Ferreira que mora na TI Kandóia também lembra da comida ruim que era dada para os Kaingang, assim como dos castigos que as lideranças indígenas - ordenadas pelo chefe - infligiam sobre os rebeldes que se recusavam a comer:

Naquela época lá, diz minha mãe que lá acima [no Toldo Votouro], o chefe botava um sino lá acima para tocar só quando estava na hora deles vir comer. Mas isso não é comer, né, não é que nem você chegar agora na mesa, ali tu tens um arroz, ali tu tens um feijão, ali tu tens uma carne, ali tu tens um pão. Não é, não era assim. Quando eles falavam de ir almoçar, né, os coitados dos indígenas vinham, os índios vinham para comer, mas eles iam só comer uma farofa, iam comer uma farofa, se tivesse carne vamos dizer, era um pedacinho assim e comer aquilo ali, um feijão meio cozido, não cozido. Tinha que comer igual, porque senão tinha a liderança com a açoiteira pronta para passar o laço. Naquela época era assim. Quem não ia, ficava no tronco, ficava no tronco e ficava sem comer. (Entrevista com Pedro Ferreira, junho de 2017, TI Kandóia).

Muitas famílias abandonaram os postos ou os toldos para fugir desse sistema de exploração e opressão, preferindo trabalhar para os colonos da região, acampando, muitas vezes, nas entradas das fazendas. Os funcionários do SPI, porém, colocavam em prática todo um sistema de controle e vigilância interna para proibir os Kaingang de saírem da área. Quando alguns deles conseguiam escapar, a "polícia indígena" - identificada nas lembranças dos Kaingang como "capitão do mato" - ia atrás dos fugitivos até encontrá-los. Pedro Ferreira lembra desse tempo no Toldo Votouro:

Alguns deles iam para lá porque o patrão precisa de peão e na época daí começou porque daí tinha serviço para eles fazerem, carpida, roçada, e os indígenas começaram a escapar aí, quiseram escapar e sair. E o chefe do posto pegava daí 
ele tinha três cavalos, pegava uma liderança, duas, e dizia "vocês vão lá". Ele sabia nome por nome e qual é a pessoa que faltava, tipo você tem uma criação na invernada, eles diziam, vocês vão lá "campeia esse fulano e traz ele, ele tem que ir trabalhar". Daí eles iam atrás do índio que escapava, chegavam lá e senão era a laço que ele vinha, era amarrado, amarrava as mãos e vinham até trazer aqui, daí ficava no tronco e depois iam a trabalhar. É bem assim que eles faziam aquela vez. E muitas vezes, como eu disse, muitas vezes, as pessoas acabavam morrendo de tanto ser judiados naqueles anos lá. Mas isso era controle do SPI, do Estado. (Entrevista com Pedro Ferreira, julho de 2017, TI Kandóia).

A "polícia indígena" - expressão do aparato militar implementado nos aldeamentos kaingang desde o fim do século XIX e que foi reforçado notadamente durante a ditadura militar - era nomeada pelo "coronel" ou "cacique" - considerado como a "mão direita" do chefe do posto - e era encarregada de vigiar o trabalho e o comportamento dos trabalhadores, além de castigar os que não se submetiam. Como ressalta o historiador kaingang Miguel Irani (2015, p. 33-34) em relação ao toldo de Inhacorá (RS), os administradores não indígenas delegavam o exercício da violência física nas mãos das lideranças indígenas de modo a não serem responsabilizados pelos danos corporais praticado sobre os Kaingang:

Ao mesmo tempo as lideranças indígenas foram manipuladas com simples favores e com um pouco de dinheiro para favorecer os servidores deste órgão e ao mesmo tempo foram usados para escravizar seus próprios irmãos indígenas, para que depois os servidores deste órgão não fossem responsáveis pelos atos que aconteciam.

Em relação ao mesmo toldo, Juracilda Veiga (2000, p. 68) apontou que "um Kaingang vestido de farda militar ficava sobre um jipe do tipo utilizado no exército e, armado com um rifle, cuidava para que aqueles que trabalhassem não fugissem". Esse modo operativo de vigilância e punição de trabalhadores em condição de superexploração tem registros históricos que parecem dar conta da sua geração e manutenção no capitalismo periférico como forma de recrutamento e encerramento da mão de obra (Moulier-Boutang, 2006; Wolf, 2009). 


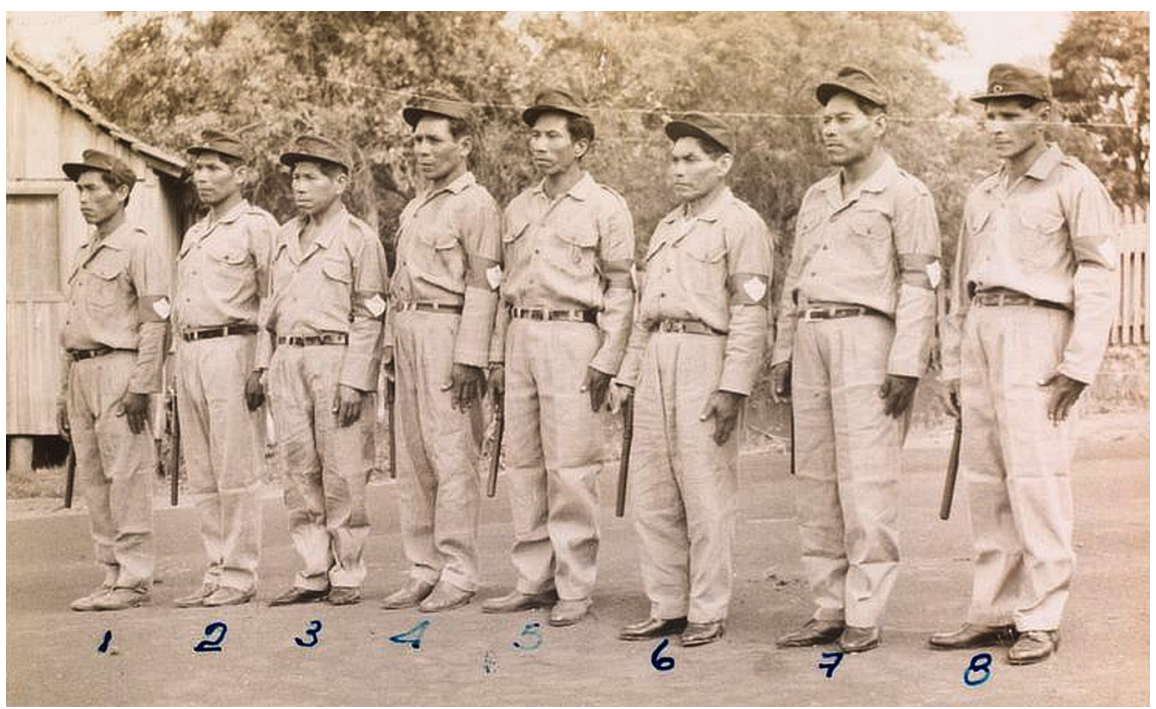

Figura 3. Formação de policiais indígenas. PI Guarita (RS), SPI - IR7, 1944. Fonte: Acervo do Museu do Índio/Funai - Brasil.

O trabalho consistia principalmente na preparação da terra, na plantação e na colheita das lavouras coletivas, consideradas por alguns Kaingang como as "lavouras do chefe". Luís da Silva lembra do trabalho nas lavouras no Toldo Votouro:

Nós trabalhava ali acima. Nós trabalhávamos um pouco ali quando eles trouxeram nós [de Ventarra]. Até a rapaziada fazia, como que se diz, eles apontavam madeira para nós fincar na terra para nós botar semente dentro porque naquele tempo não existia, era plantar à mão. Eles faziam nós trabalhar de enxada, faziam nós limpar as roças. Assim, prantava, roçava, queimava e nós plantava, né, com aquele pau que abria a terra pra nós prantar. Eles botavam nós em fileira, desde os 10 anos já trabalhavam, né. Depois nós colhia para nós, né, para nós sobreviver, né. Plantávamos mandioca, moranga, para nós passar cada ano, né. Eles [o chefe do posto e as lideranças] tinham a comissão deles, e porque era para nós ganhar na época uma comida só, né. Não era nada de dinheiro. (Entrevista com Luís da Silva, julho de 2017, TI Kandóia). 


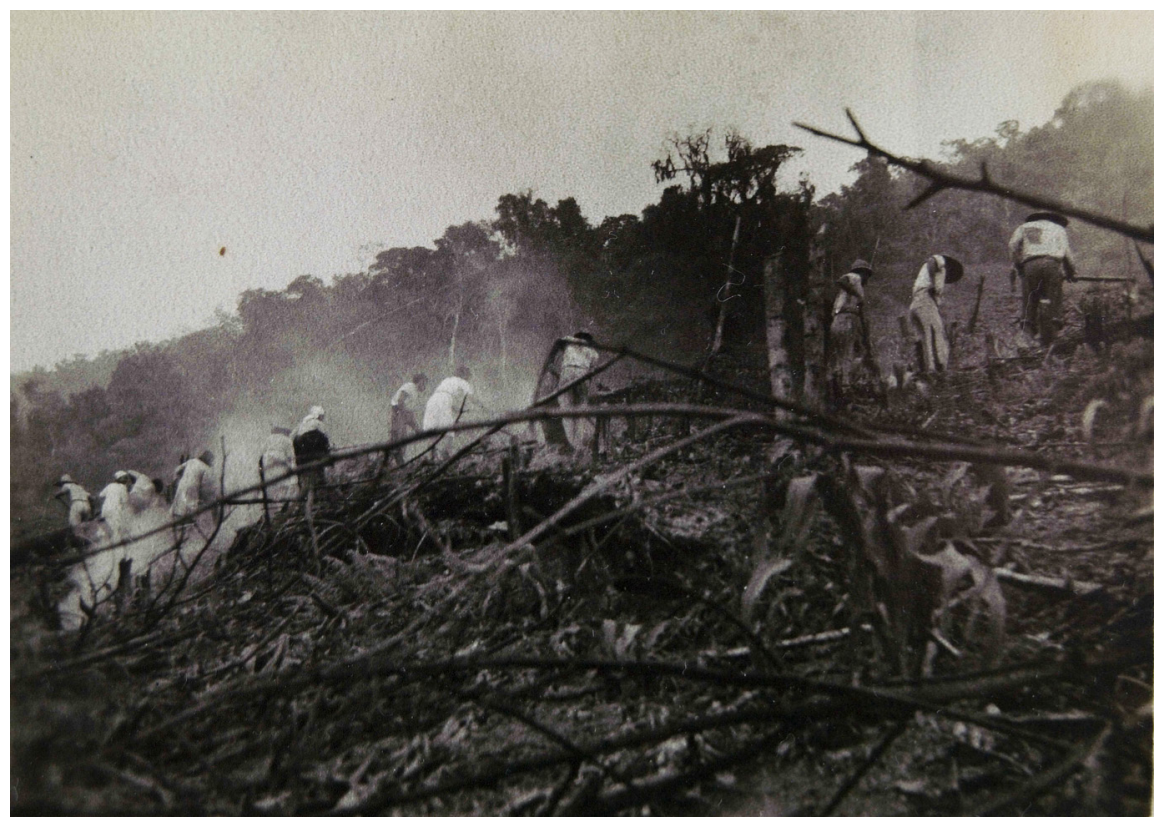

Figura 4. Kaingang trabalhando em lavouras coletivas no PI Nonoai (RS) - SPI/IR7, 1944. Fonte: Acervo do Museu do Índio/Funai - Brasil.

Essas lavouras coletivas comandadas pelos administradores dos órgãos indigenistas estatais passaram por cima da organização socioeconômica e política dos Kaingang "impondo atividades coletivas entre grupos que tradicionalmente estavam separados e separando grupos que realizavam atividades conjuntas" (Almeida, L., 2004, p. 225). Desequilibrando essa organização, os funcionários fomentaram a centralização política e estimularam o nascimento de elites econômicas e políticas poderosas. Esse novo sistema econômico e político, no interior dos PI e toldos kaingang, conforme L. Almeida (2004, p. 225), “[...] desarticulou unidades produtivas importantes e rompeu de forma agressiva os sistemas de trocas locais". Porém, a desestruturação das unidades produtivas não foi total porque o sistema estabelecido pela dinâmica do panelão era fundamental à reprodução das economias domésticas indígenas como forma de assegurar a própria reprodução da força de trabalho durante os períodos dos meses não produtivos (Meillassoux, 1975). Esses processos incluíam, dessa forma, tanto o aproveitamento da organização 
produtiva da unidade doméstica quanto as formas organizativas e de gestão de poder dos Kaingang.

Em vários PI foram organizados os "Conselhos dos Índios", que hoje ainda existem nas TI. Esses conselhos tinham por objetivo reunir os indígenas para que participassem da vida do posto. O conselho era presidido simbolicamente por uma liderança indígena e composto por vários representantes indígenas que se reuniam mensalmente - ou quando necessário - para tomar decisões em relação à vida interna das aldeias (chegada de novas famílias vindas de outras áreas; julgamento sobre abuso de álcool ou brigas envolvendo indígenas; encaminhamentos sobre a escola; cuidados aos velhos; estatísticas sobre produção agrícola do posto; e aplicação de verbas, além de demais orientações sobre o trabalho dos indígenas) (Bringmann, 2015). Nessa ordem, Simonian (1981 apud Bringmann, 2015, p. 252), analisando o “Conselho dos Índios" em Nonoai, considera que os funcionários souberam utilizar um sistema antigo kaingang e adaptá-lo às necessidades produtivas do SPI. No sistema antigo kaingang, os conselheiros eram escolhidos pelos kofá (anciãs, sábios) e se reuniam para tomar decisões relativas à vida na aldeia, além de mediarem as situações de conflito (Bringmann, 2015).

Segundo Simonian (1981) e Brigmann (2015), os chefes do posto teriam se apropriado do antigo conselho para melhorar as atividades produtivas do SPI no interior dos PI. O encarregado fóg (denominação kaingang para os não indígenas) passou a ocupar o papel de mediador/orientador no seio do conselho quando se tratavam dos temas relacionados à produção agrícola e acabou controlando a maioria das decisões tomadas nessa instância (Bringmann, 2015). O conselho, reapropriado e reconfigurado pelo chefe do posto, passou a servir como um instrumento de fiscalização e levantamento da produtividade indígena.

Paralelamente ao sistema de panelão, que se conformou como uma modalidade de organização e exploração do trabalho dos Kaingang, existiam também os chamados puxirões, que consistiam na ajuda comunitária entre unidades domésticas kaingang a pedido de alguma das famílias. Os Kaingang se reuniam e trabalhavam no terreno dessa família em tarefas como a construção da casa, o plantio na lavoura familiar, etc. Em troca, a família lhes dava comida e bebida (Bringmann, 2015). Esses puxirões, porém, eram de certa utilidade para o SPI porque permitiam acostumar os Kaingang ao trabalho agrícola, reduzindo 
alguns dos impactos mais diretos da exploração no panelão. Além disso, também permitiam fortalecer, e ao mesmo controlar, o tecido social entre as diversas famílias kaingang que participavam dos puxirões, pois, após o trabalho, elas eram autorizadas a comemorar juntas.

Para os funcionários do SPI, todos os indígenas que integravam uma unidade doméstica deviam se esforçar para colaborar com a intensificação da produtividade. Para isso, o SPI decretou que nenhum tipo de assistência seria dada de forma gratuita aos indígenas: "o índio perde a atividade e não adquire a noção normal e indispensável do trabalho e do comércio, incorpora-se à sociedade brasileira com a mentalidade de parasita e mendigo, como se vê frequentemente" (Brasil/SPI, 1941 apud Almeida, C., 2017, p. 145). Nas escolas, os funcionários decidiram fomentar a vontade dos jovens kaingang para a agricultura mediante a entrega de prêmios para os melhores alunos (Bringmann, 2017, p. 153). Esses prêmios iam desde sabão até animais de carga: "aos índios que mais serviço tem prestado ao posto e a família indígena são dados prêmios de animais para servir de estimulo" (Brasil/SPI, 1945 apud Bringmann, 2017, p. 153).

Porém, com a imposição das lavouras coletivas e, de maneira geral, com o trabalho forçado, as relações de produção socioeconômicas e cosmológicas dos Kaingang vieram a se transformar consideravelmente. As caminhadas na floresta que visavam a formação dos mais jovens se reduziram e foram trocadas pelo trabalho explorado. Todas as pessoas da unidade familiar tiveram que se incorporar, forçosamente, à dinâmica produtivista imposta pelo órgão estatal. Pedro Ferreira nos relata:

Ali era mulher, era os homens, eram crianças. Não era que nem que hoje que as crianças de 6 ou 7 anos estão todos na escola. Naquele tempo, de 7 anos para cima ia na lavoura, e não vai para ver, de pé no chão. Muitas vezes, se tu vai lembrar agora e vai trabalhar acima disso tu chora, de tanta aflição que eles tinham aquela vez. De pé no chão, carpindo para semear o trigo, era obrigado a fazer senão o laço pegava, e frio e tinha que ir igual. Roupa, aquela vez lá, muitas vezes que tanto que tu estavas trabalhando tu estavas com as roupas tudo em fiapo, estava terminando no teu corpo e tu tinhas que trabalhar igual. (Entrevista com Pedro Ferreira, julho de 2017, TI Kandóia). 


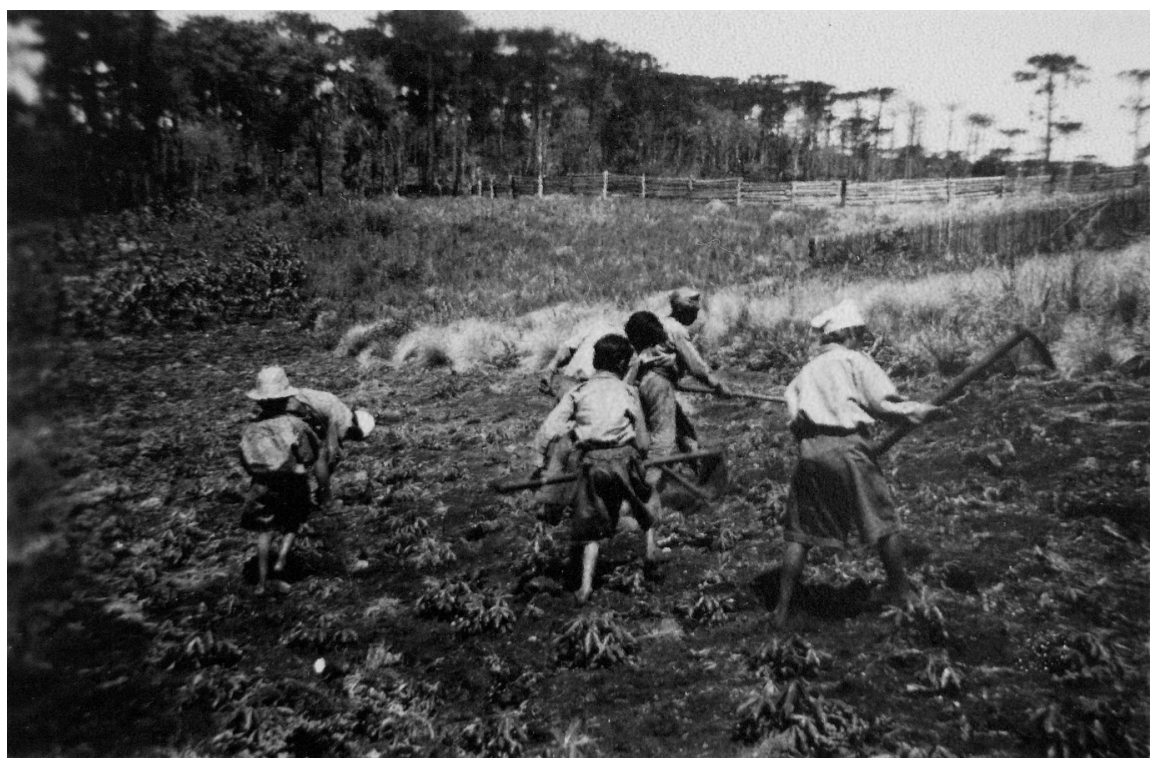

Figura 5. Crianças kaingang trabalhando. PI Ligeiro (RS) - SPI/IR7, 1944. Fonte: Acervo do Museu do Índio/Funai - Brasil.

O sistema de panelão estava fundado no objetivo de estimular a competitividade entre os indígenas de modo a incrementar a produtividade. Foi através de diferentes "programas" que o SPI tentou inserir os Kaingang na produção agrícola regional e nacional. A "Campanha do Trigo" foi um projeto iniciado em 1944 frente à demanda nacional do produto e envolveu os indígenas dos postos da Inspetoria Regional 7 (principalmente os Kaingang dos estados de Paraná, Santa Catarina e Rio Grande do Sul). Com os resultados positivos de tais empreendimentos, o SPI afirmou em 1958:

O índio já deixa de ser um simples participante da economia regional, para competir e assumir posição de liderança ao mesmo tempo que os Postos se tornam centros de progresso e incremento da lavoura. (Brasil/SPI, 1958, p. 3 apud Nötzold; Bringmann, 2013, p. 158).

Os Kaingang foram forçados a participar das Exposições Agrícolas Estaduais para competir com colonos da região. Alcançaram até prêmios na Festa 
Nacional do Milho em 1954: os indígenas do PI Guarita foram condecorados com medalha de prata para suas plantações de milho e feijão. A competição era estimulada também em nível interno entre os próprios Kaingang. Nessa mesma Festa do Milho de 1954, 14 indígenas de Guarita receberam individualmente uma medalha de prata (Brasil/SPI, 1954, p. 38 apud Rocha, 2003, p. 115).

O comércio de madeira também foi muito explorado na região Sul do país. Antônio Tonatto, descendente de italiano e morador da região de Votouro, lembra que seu pai montava serrarias "movidas à água" na região:

Meu pai era construtor, o SPI contratou ele como engenheiro. Construiu um engenho aqui no Barro Preto ${ }^{10} \mathrm{e}$ daí ele veio ensinar a trabalhar um pouco, daí veio a montar uma serraria aqui no Faxinal, tinha tanto pinheiro na época. (Entrevista com Antônio Tonatto, agosto de 2017, TI Kandóia).

Assim, os Kaingang foram recrutados para o corte de pinheiros e obrigados a desmatar seu próprio território.

Rocha (2003, p. 116), bem como Nötzold e Bringmann (2013, p. 160), afirmam que essa combinação entre a produção tritícola, a exploração de madeira e a pecuária teria contribuído para instaurar uma "situação de empresa" (Cardoso de Oliveira, 1964; 1972). Os encarregados dos postos e dos toldos apresentavam-se como patrões dos indígenas, que, por sua vez, eram considerados por eles como seus empregados. Tal "situação de empresa", derivada da exploração do trabalho capitalista, deve ser apreendida segundo suas especificidades. A exploração do trabalho indígena ocorreu por meio da representação governamental do Estado brasileiro que, através dos órgãos indigenistas, organizou: 1) a espoliação dos territórios indígenas; e 2) a exploração de todos seus habitantes. Efetivamente, todos os membros das comunidades kaingang tiveram que trabalhar. As mulheres cozinhavam ou trabalhavam nas lavouras; os homens trabalhavam nas lavouras, cortavam

10 O Barro Preto, ou Ore Xá, é um local situado na atual TI Kandóia, hoje ocupada por moradores e produtores rurais não indígenas. Os Kaingang estão à espera da demarcação dos 5800 hectares da TI Kandóia há quase 20 anos. Por enquanto, eles estão cercados em 2 hectares de terras, vivendo em uma situação muito precária (Maréchal, 2017). 
madeira ou abriam estradas; e as crianças eram exploradas na roça após uma breve passagem na escola, como os Kaingang Luís da Silva e Pedro Ferreira relataram anteriormente.

A ideia do SPI era que os indígenas chegassem a ser "autossuficientes" e que logo pudessem, por si sós, competir no mercado rural e, assim, favorecer a economia regional e nacional. O sistema implementado pelo órgão indigenista era um sistema de exploração do trabalho no qual os Kaingang eram "remunerados" com comida. Eles eram alimentados nos dias de trabalho (panelão) e autorizados a colher uma parte do que tinham plantado para a subsistência da sua família. Porém, o SPI não se limitou a criar um sistema de produção de autossuficiência. A ideia do órgão era a produção e comercialização de excedente mediante a exploração do trabalho dos Kaingang. O dinheiro ganho com a comercialização dos excedentes ficou conhecido como "renda do patrimônio indígena" ou "renda indígena". Esse dinheiro servia efetivamente ao fortalecimento do projeto civilizatório, permitindo investir em postos de saúde, escolas, salões de festas, terrenos de futebol, etc. Porém, muito desse dinheiro acabou "desaparecendo" da vista dos trabalhadores kaingang. Pedro Ferreira relata:

Tu plantavas e tinhas que vir a colher, tu colhias, mas tu não vias para onde que ia. Eles lá, a liderança com o chefe do SPI era quem comandava isso aí. Eles diziam, armazenava para comprar isso e aquilo para os índios. Mas no fim não comprava nada e os índios ficavam ali. (Entrevista com Pedro Ferreira, julho de 2017, TI Kandóia).

Todos os Kaingang com quem conversamos em relação àquela temporada afirmam que nunca foram pagos em dinheiro pelo seu trabalho. Nas lembranças, os órgãos estatais lhes davam comida suficiente para sobreviver e seguir trabalhando nos dias seguintes. Os Kaingang do Toldo Votouro passaram a comercializar sua produção em Erechim (RS), como relata Pedro Ferreira:

Tudo o que tu colhias aqui não tinha como você vender, não tinha balança, não tinha caminhão para pegar nada, daí tu botavas na tropa e levavas lá em Erechim, nesse Paiol. Lá, daí, você vendia e comprava o alimento para você trazer para cá para você comer. (Entrevista com Pedro Ferreira, julho de 2017, TI Kandóia). 
Porém, trata-se aqui não dos excedentes de produção, mas da produção que correspondia ao necessário para a subsistência dos Kaingang. Os Kaingang buscavam comercializar esses produtos para que pudessem comprar alimentos e bens que não eram produzidos nem fornecidos nos toldos. Para isso, tinham que levar sua produção nas carroças até Erechim, situada a aproximadamente 40 quilômetros do Toldo Votouro.

Além disso, a superprodução acabava se perdendo na burocracia do órgão federal ou nos bolsos dos funcionários (Santos, 1970, p. 63). Muitos conflitos aconteceram em relação à renda indígena entre lideranças, funcionários do SPI e trabalhadores kaingang. Esses conflitos acabaram por dar abertura aos arrendamentos oferecidos pelos órgãos estatais a agricultores da região - o que se prolongou, inclusive, durante a gestão da Funai. Os colonos utilizavam a terra em prol de uma agricultura comercial baseada na monocultura de cereal e os Kaingang passaram a trabalhar como peões para tais colonos, que pagavam um "aluguel" aos funcionários dos órgãos indigenistas para poder explorar a terra. Esses funcionários, por sua vez, para convencer as lideranças indígenas a se associar aos negócios do órgão, favoreciam-nas com algumas "regalias". A situação descrita provocou o nascimento de uma aristocracia indígena e está na origem da produção e reprodução de uma série de desigualdades sociais em algumas TI. A exploração de madeira também foi feita com base em negócios escusos por parte de muitos funcionários da Funai. Antônio Tonatto, em referência à área indígena Votouro, comenta: "Esses administradores dos toldos indígenas ficaram todos ricos com a venda de pinheiro."

A exploração do trabalho dos Kaingang no início do século XX até o fim da ditadura militar foi marcada pela onipresença dos órgãos estatais nos toldos kaingang. ${ }^{11}$ Encarregados de uma missão civilizatória, despossuíram os Kaingang das suas relações de produção. A floresta nãn foi, pouco a pouco, transformada em lavoura, em um deserto verde. Os pinheiros fág foram derrubados, muitas vezes, pelos próprios Kaingang, coagidos pelos funcionários do governo

11 Em 1967, o SPI é extinto. Nasce então a Fundação Nacional do Índio (Funai), que reproduziu até o fim da ditadura militar os mesmos métodos de atuação do antigo órgão indigenista. Essa continuidade se expressa pela memória dos Kaingang, que nos seus relatos ou fazem referência ao SPI em um período posterior a 1967, ou afirmam que a atuação dos dois órgãos era basicamente "a mesma coisa". 
e pela vigilância da polícia indígena. Impossibilitadas pelos processos de expansão do capital, a caça, a pesca e a colheita foram diminuindo.

A subjugação dos Kaingang ao sistema capitalista fez-se por via do Estado que, através da exploração da sua força de trabalho, manipulou as forças de acumulação do capital com o intuito de assegurar o padrão mais vantajoso para os interesses capitalistas dominantes (Harvey, 2003). A despossessão das relações de produção dos Kaingang por parte do órgão estatal foi praticada como estratégia de reprodução do capital. Foi necessário tornar os Kaingang dependentes da assistência do Estado, uma dependência que atuou como uma ferramenta indispensável para a otimização da exploração do seu trabalho. Ela implicou um desequilíbrio nas relações sociais, políticas e espirituais entre os Kaingang, que passaram a ser considerados como "índios trabalhadores". Essa combinação foi pressuposta pelos agentes estatais e colonos como direito de exploração da força de trabalho dos Kaingang, tratados como mão de obra extremamente barata por conta da condição étnica reconhecida por eles - e compartilhada nos imaginários da sociedade brasileira - como inferior.

Nesse sentido, o projeto civilizatório levado a cabo pelo SPI e pelo governo do estado do Rio Grande do Sul não somente procurou diluir as diversas identidades étnicas na identidade nacional (ou regional, no caso do governo do estado do Rio Grande do Sul) - ressignificando a categoria étnica "índio" ao incorporá-la à nova classificação social hierárquica - como conseguiu fazer com que essa inferioridade étnica - reforçada e reproduzida pela ideologia nacionalista - servisse, mediante a exploração do trabalho indígena, ao desenvolvimento e ao progresso econômico da nação brasileira.

\section{Capitalismo colonial/moderno e subsunção formal do trabalho kaingang no Alto Uruguai}

A exploração do trabalho dos Kaingang no tempo do SPI no Rio Grande do Sul - através da articulação entre a instauração do sistema de panelão, a reprodução social dos puxirões e a apropriação do conselho como forma de organização política kaingang pelos funcionários - pode ser entendida a partir de diversos processos que se articulam de forma heterogênea na orientação de subsumir os grupos kaingang com o intuito de absorvê-los dentro das relações próprias 
do capitalismo colonial/moderno. Uma das caraterísticas centrais das formações sociais periféricas é a disposição articulada de diversas formas de controle do trabalho que atuam de maneira contraditória mas continuada na reprodução do capitalismo, e que funcionam integrando, de maneira forçada, elementos de subsistemas econômicos e socioculturais não capitalistas (Meillassoux, 1975). Nesse sentido, as formas de superexploração do trabalho nas periferias combinam-se com a (re)produção de sistemas de classificação e hierarquização social que fundamentam formas de dominação subjetiva responsáveis por assegurar, ao mesmo tempo, a proliferação das dinâmicas capitalistas (Wallerstein, 1996). Longe de pensar as etnicidades e identidades sociais como um resultado das relações capitalistas ou como um movimento totalmente autônomo das populações indígenas, elas devem ser analisadas historicamente como conglomerados de produção de relações de identidades/alteridades em disputa dentro de relações específicas de poder, nas quais intervêm tanto as populações locais quanto o Estado e o capital.

Desde esse marco, o Estado brasileiro, através do SPI e do governo do estado do Rio Grande do Sul, em aliança com diversas facções do capital da região do Alto Uruguai, aproveitou-se das políticas indigenistas de integração para desenvolver um modelo de captura do trabalho indígena kaingang com a intenção de integrá-los à sociedade nacional. Tais movimentos só são possíveis tendo como precondição uma formação social desigual e fortemente hierarquizada que, através da ideia de "raça", classifica os indígenas (e outras populações) como inferiores e, precisamente por isso, os torna suscetíveis de serem superexplorados. Esses dispositivos de classificação social fundamentam-se em imaginários sociais coloniais (Stoler; Cooper, 2013) geradores de mitos associados às relações entre capital e trabalho, produzindo as narrativas dos indígenas preguiçosos, dóceis, ignorantes e selvagens, contrapostos aos migrantes europeus esforçados, trabalhadores, astutos e civilizados (Alatas, 2010; Quintero, 2013). É por isso que a colonialidade do poder continua sendo a base das relações sociais na América Latina (Quijano, 2000). Basta comparar as políticas estatais desenvolvidas para cada grupo a fim de perceber a atuação de tais imaginários.

De modo contraditório, as práticas de subjetivação social do capitalismo colonial/moderno alçam as bandeiras da integração e da mudança cultural como necessárias para a civilização/modernização das populações dominadas, enquanto as dinâmicas de exploração econômica se aproveitam precisamente 
das vantagens reprodutivas dos subsistemas não capitalistas. No capítulo XXIV de O capital, Karl Marx (2014) denominou a "acumulação originária" como o processo de produção que, fora do sistema capitalista, representa, porém, o ponto de partida da acumulação deste sistema ("a pré-história do capital") na medida em que o produtor prescinde dos seus meios de produção. Certamente esse processo constitui umas das bases centrais do capitalismo. Contudo, a acumulação originaria não desaparece na "história do capital", mas, na verdade, apresenta-se constantemente em diversos ciclos históricos de acumulação capitalista (Luxembourg, 1967) e, particularmente, nas formações periféricas do capitalismo colonial/moderno. Para analisar as modalidades de subordinação dos Kaingang do Alto Uruguai pelo Estado e pelo capital é mais conveniente afastar-se da ideia de acumulação originária e aproximar-se das categorias da subsunção. Desenvolvidas de maneira parcial pelo próprio Marx (2013) nos Grundrisse, elas foram introduzidas na prática da pesquisa antropológica de uma forma diferente por autores como Ann Laura Stoler (1987, 1995), Claude Meillassoux (1975) e Maurice Godelier (1987), isto é, enquanto modo de analisar os chamados processos de transição ao capitalismo.

A história da subordinação dos grupos kaingang no Alto Uruguai parece responder aos processos gerais de subsunção do trabalho ao capital. A subsunção representa um processo identificável na história das relações entre os Kaingang e o SPI tanto na memória histórica kaingang coletada no trabalho etnográfico quanto nas fontes secundárias disponíveis, correspondendo à demonstração das dinâmicas de dominação e exploração do processo de trabalho doméstico e/ou comunal dos Kaingang e à sua incorporação no processo de valorização do capital através do controle estatal dos grupos kaingang, assim como à incorporação forçada às dinâmicas de acumulação a partir dos processos já assinalados neste artigo: a) expropriação dos territórios e acumulação originária; b) sedentarização, realocação e controle repressivo da população; c) reconfiguração da organização social e econômica; e d) dependência do setor capitalista para reprodução da vida.

A categoria subsunção distingue duas formas de expressão prática: a subsunção formal e a subsunção real. A subsunção formal se diferencia da subsunção real pelos modos como o capital subordina a mão de obra, seja destruindo a base material e/ou as relações sociais dos modos de produção precedentes, seja conservando e refazendo certos traços de tais relações (Stoler, 1987). Segundo 
Marx (1976 apud Stoler, 1987, p. 104), sob a subsunção formal a produção capitalista pode "absorver um processo existente de trabalho que se desenvolveu sob modos de produção diferentes e mais arcaicos". A subsunção real acontece quando o capital desenvolveu suas próprias forças de produção, mediante novas técnicas de produção, que, dessa maneira, transformam essencialmente as relações do trabalhador em relação ao capital e ao trabalho.

Logo, a subsunção pode acontecer no processo do trabalho e/ou nas relações sociais nas quais reproduzem a força de trabalho. O caso dos Kaingang do Alto Uruguai pode ser tratado como um exemplo específico de subsunção formal que se formaria a partir dos PI e dos toldos kaingang sob a gestão do SPI e do governo do estado do Rio Grande do Sul através da imposição do sistema das lavouras coletivas, o panelão, temporizado com o trabalho comunitário adaptado a um sistema de organização e produção mais antigo, o puxirão. Os dois sistemas em questão são articulados ao redor do conselho, estrutura política kaingang antiga que foi reconfigurada de acordo com as necessidades produtivas do órgão estatal. Essa articulação político-econômica, porém, só pôde funcionar sob o subjacente controle social exercido pelo chefe do posto e reproduzido pelas lideranças indígenas militarizadas associadas a ele.

\section{Referências}

ALATAS, S. H. The myth of the lazy native. New York: Routledge, 2010.

ALMEIDA, C. "Era um pinhalão [...] mato, mato virgem!": As múltiplas faces da proteção tutelar entre os Kaingang do Xáembetkó. In: NÖTZOLD, A. L. V.; ROSA, H. A.; BRINGMANN, S. F. (org.). História, cultura e educação indígena: protagonismo e diversidade. Porto Alegre: Universidade Federal de Santa Catarina: Palloti, 2017. p. 109-132.

ALMEIDA, L. K. Análise antropológica das igrejas cristãs entre os Kaingang, baseada na etnografia, na cosmologia e no dualismo. 2004. Tese (Doutorado em Antropologia Social) - Universidade Federal de Santa Catarina, Florianópolis, 2004.

BECKER, I. B. O índio Kaingang no Rio Grande do Sul. São Leopoldo: Universidade do Vale do Rio dos Sinos, 1976.

BONFIL BATALLA, G. Notas sobre civilización y proyecto nacional. Cuadernos Politicos, México, n. 52, p. 21-31, 1987. 
BRAGA, D. A história dos Kaingang na luta pela terra no Rio Grande do Sul: do silêncio à reação, à reconquista e a volta para casa. 2015. Dissertação (Mestrado em História) Instituto de Filosofia e Ciências Humanas, Universidade Federal do Rio Grande do Sul, Porto Alegre, 2015.

BRASIL. Decreto n. 426 - de 24 de julho de 1845. Contém o Regulamento ácerca das Missões de catechese, e civilisação dos Iudios. Rio de Janeiro, 1845. Disponível em: http://legis.senado.leg.br/norma/387574/publicacao/15771126. Acesso em: 23 set. 2019.

BRASIL. Lei $n^{0}$ 601, de 18 de setembro de 1850. Dispõe sobre as terras devolutas do Império. Rio de Janeiro, 1850. Disponível em: http://www.planalto.gov.br/ccivil_03/ leis/lim/LIM601.htm. Acesso em: 23 set. 2019.

BRINGMANN, S. F. Entre os índios do sul: uma análise da atuação indigenista do SPI e de suas propostas de desenvolvimento educacional e agropecuário nos Postos Indígenas Nonoai/RS e Xapecó/SC (1941-1967). 2015. Tese (Doutorado em História) - Centro de Filosofia e Ciências Humanas, Universidade Federal de Santa Catarina, Florianópolis, 2015.

BRINGMANN, S. F. Narrativas singulares, experiências coletivas: história, memória e protagonismo Kaingang em tempos de SPI. In: NÖTZOLD, A. L. V.; ROSA, H. A.; BRINGMANN, S. F. (org). História, cultura e educação indígena: protagonismo e diversidade. Porto Alegre: Universidade Federal de Santa Catarina: Palloti, 2017. p. 133-160.

CARDOSO DE OLIVEIRA, R. O índio e o mundo dos brancos. São Paulo: Difusão Européia do Livro, 1964.

CARDOSO DE OLIVEIRA, R. A sociologia do Brasil indígena. Rio de Janeiro: Tempo Brasileiro, 1972.

FREIRE, C. A. (org.). Memória do SPI: textos, imagens e documentos sobre o Serviço de Proteção aos Índios (1910-1967). Brasília: Museu do Índio/Funai, 2011.

GODELIER, M. La production des grands hommes. Paris: Fayard, 1982.

GODELIER, M. Análisis de los procesos de transición. Revista Internacional de Ciencias Sociales, n. 114, p. 5-16, 1987.

GONZÁLEZ CASANOVA, P. La democracia en México. México: Era, 1965.

HARVEY, D. El nuevo imperialismo. Madrid: Akal, 2003. 
IRANI, M. K. Ëg sï ag kar pã ï ag tÿ nén ü veja kãmén ge SPI to Ëmã Inhacorá tá: o Serviço de Proteção ao Índio (SPI) na visão dos anciões e lideranças do povo Kaingang da Terra Indígena Inhacorá (São Valério do Sul, Rio Grande do Sul). 2015. Trabalho de Conclusão de Curso (Licenciatura Intercultural Indígena do Sul da Mata Atlântica) - Centro de Filosofia e Ciências Humanas, Universidade Federal de Santa Catarina, Florianópolis, 2015.

LAROQUE, L. F. S. Lideranças Kaingang no Brasil meridional (1808-1889). São Leopoldo: Instituto Anchietano, 2000.

LIMA, A. C. de S. O governo dos índios sob a gestão do SPI. In: CARNEIRO DA CUNHA, M. (org.). História dos índios do Brasil. São Paulo: Companhia das Letras, 1992. p. 155-172.

LIMA, A. C. de S. Um grande cerco de paz: poder tutelar, indianidade e formação de Estado no Brasil. Petrópolis: Vozes, 1995.

LUXEMBOURG, R. La acumulación de capital. México: Grijalbo, 1967.

MARÉCHAL, C. Sonhar, curar, lutar: colonialidade, xamanismo e cosmopolítica Kaingang no Rio Grande do Sul. Curitiba: Prismas, 2017.

MARX, K. Manuscritos econômico-filosóficos. São Paulo: Boitempo, 2010.

MARX, K. Grundrisse: esboços da crítica da economia política. São Paulo: Boitempo, 2013.

MARX, K. O capital: livro I. São Paulo: Boitempo, 2014.

MEILLASSOUX, C. Femmes, greniers et capitaux. Paris: Maspero, 1975.

MOTA, L. T. A denominação Kaingang na literatura antropológica, histórica e linguística. In: TOMMASINO, K.; MOTA, L. T.; NOELLI, F. S. (org.). Novas contribuições aos estudos interdisciplinares dos Kaingang. Londrina: Eduel, 2004. p. 3-16.

MOULIER-BOUTANG, Y. De la esclavitud al trabajo asalariado: economía históica del trabajo asalariado embriado. Madrid: Akal, 2006.

NÖTZOLD, A. L. V.; BRINGMANN, S. F. O Serviço de proteção aos Índios e os projetos de desenvolvimento dos Postos Indígenas: o Programa Pecuário e a Campanha do Trigo entre os Kaingang da IR7. Revista Brasileira de História e Ciências Sociais, v. 5, n. 10, p. 1-18, 2013.

PACHECO DE OLIVEIRA, J. Terras indígenas, economia de mercado e desenvolvimento rural. In: PACHECO DE OLIVEIRA, J. (org.). Indigenismo e territorialização: poderes, rotinas e saberes coloniais no Brasil contemporâneo. Rio de Janeiro: Contra Capa, 1998. p. 43-68. 
PACHECO DE OLIVEIRA, J. Uma etnologia dos "índios mixturados"? Situação colonial, territorialização e fluxos culturais. In: PACHECO DE OLIVEIRA, J. (org.). A viagem da volta: etnicidade, política e reelaboração cultural no Nordeste indígena. Rio de Janeiro: Contra Capa, 2004. p. 13-38.

PACHECO DE OLIVEIRA, J. Regime tutelar e faccionalismo: política e religião em uma reserva Ticuna. Manaus: Universidade Estadual de Amazonas, 2015.

PACHECO DE OLIVEIRA, J. O nascimento do Brasil e outros ensaios: "pacificação", regime tutelar e formação de alteridades. Rio de Janeiro: Contra Capa, 2016.

QUIJANO, A. Colonialidad y modernidad/racionalidad. Perú Indígena, Lima, v. 13, n. 29, p. 11-20, 1992.

QUIJANO, A. Colonialidad del poder y clasificación social. Journal of Wolrd Systems Research, v. 6, n. 2, p. 342-388, 2000.

QUIJANO, A. “Solidaridad" y capitalismo colonial/moderno. Otra Economía, Buenos Aires, v. 2, n. 2, p. 11-16, 2008.

QUINTERO, P. Programas de desarrollo y comunidades indígenas en el Chaco central: capitalismo y colonialidad del poder en una formación social de fronteras. 2013. Tese (Doutorado em Antropologia) - Universidad de Buenos Aires, Buenos Aires, 2013.

QUINTERO, P. Notas sobre la teoría de la colonialidad del poder y la estructuración de la sociedad en América Latina. In: QUIJANO, A. (ed.). Des/colonialidad y bien vivir: un nuevo debate en América Latina. Lima: Universidad Ricardo Palma, 2014. p. 193-216.

QUINTERO, P. A colonização do Chaco argentino: processos de territorialização, expansão do capital e colonialidade na “Guerra conta el Indio" (1875-1917). In: MURA, F.; SECUNDINO, M. A.; SILVA, A. B. (org.). Povos indígenas e relações de poder: olhares sobre América do Sul. Brasília: Associação Brasileira de Antropologia: Universidade Estadual da Paraíba, 2019. p. 147-178.

RAMOS, A. Indigenism: etnic politics in Brasil. Madison: Univesity of Wisconsin, 1998.

ROCHA, L. M. A política indigenista no Brasil (1930-1967). Goiânia: UFG, 2003.

ROSA, R. R. G. Os kuja são diferentes: um estudo etnológico do complexo xamânico dos Kaingang da Terra Indígena Votouro. 2005. Tese (Doutorado em Antropologia Social) - Instituto de Filosofia e Ciências Humanas, Universidade Federal do Rio Grande do Sul, Porto Alegre, 2005.

SANTOS, S. C. A integração dos índios na sociedade regional: a função dos postos indígenas em Santa Catarina. Florianópolis: Universidade Federal de Santa Catarina, 1970. 
SCHADEN, F. O cacique Doble e sua horda. In: SCHADEN, F. (org.). Índios, caboclos e colonos: páginas de etnografía, sociologia e folclore. São Paulo: Universidade de São Paulo, 1963. p. 67-75.

SIMONIAN, L. T. Terra de posseiros: um estudo sobre as políticas de terras indígenas. 1981. Dissertação (Mestrado em Antropologia Social) - Museu Nacional, Universidade Federal do Rio de Janeiro, Rio de Janeiro, 1981.

SIMONIAN, L. T. Os indigenas de Ventarra e seus direitos territoriais. [S.l.]: [s.n.], 1994. Laudo antropológico.

SIMONIAN, L. T. Política/ação anti-indígena de Leonel de Moura Brizola. In: BOEIRA, N.; GOLIN, T. História geral do Rio Grande do Sul: povos indígenas: v. 5. Passo Fundo: Méritos, 2009. p. 469-496.

STAVENHAGEN, R. Las clases sociales en las sociedades agrarias. México: Siglo XXI, 1969.

STOLER, A. L. Transiciones en Sumatra: el capitalismo colonial y las teorías sobre la subsunción. Revista Internacional de Ciencias Sociales, n. 114, p. 103-123, 1987.

STOLER, A. L. Capitalism and confrontation in Sumatra's plantation belt, 1870-1979. Ann Arbor: University of Michigan Press, 1995.

STOLER, A. L.; COOPER, F. Repenser le colonialisme. Paris: Payot, 2013.

TOMMASINO, K. A história dos Kaingáng da bacia do Tibagi: uma sociedade jê meridional em movimento. 1995. Tese (Doutorado em Antropologia Social) - Faculdade de Filosofia, Letras e Ciências Humanas, Universidade de São Paulo, São Paulo, 1995.

VEIGA, J. Cosmologia e práticas rituais Kaingang. 2000. Tese (Doutorado em Antropologia Social) - Instituto de Filosofia e Ciências Humanas, Universidade Estadual de Campinas, Campinas, 2000.

VELHO, O. Frentes de expansão e estrutura agrária. Rio de Janeiro: Zahar, 1981.

WALLERSTEIN, I. El capitalismo histórico. México: Siglo XXI, 1996.

WOLF, E. Europa e os povos sem história. São Paulo: Edusp, 2009.

Recebido: 30/09/2019 Aceito: 27/04/2020 | Received: 9/30/2019 Accepted: 4/27/2020 